\title{
The Development of Audouinia tentaculata (Montagu).
}

\author{
By \\ Douglas P. Wilson, M.Sc., \\ Assistant Naturalist at the Plymouth Laboratory.
}

With 12 Figures in the Text.

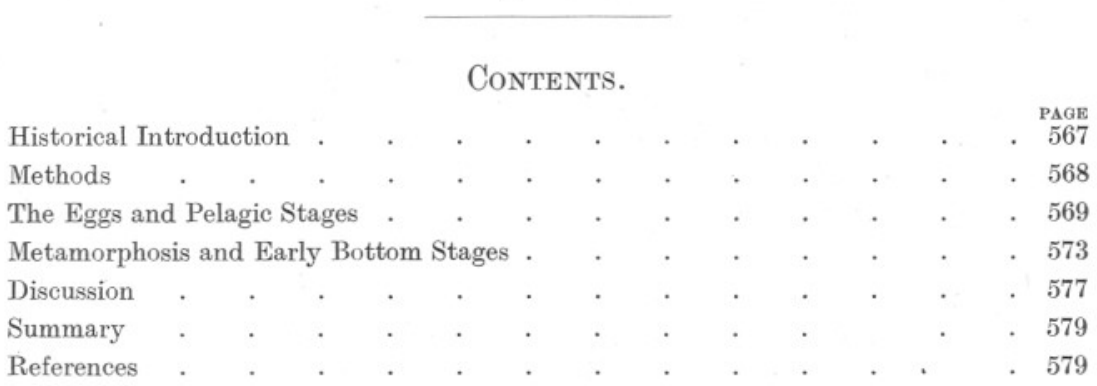

Historical Introduction.

LitTLE is known about the development of the Cirratulidæ. The earliest record of young stages is that of Claparède and Mecznikow who in 1868 described and figured in colour two young Cirratulid worms, one with nine setigers being ascribed to Audouinia filigera. It had two pairs of branchiæ, the first pair arising anterior to the first pair of bristle bundles. The other specimen belonged to a viviparous species and had been removed from the body cavity of the parent. It had five to six bristlecarrying segments, two pairs of long branchiæ, and buds of others. The species was not identified. Both types corresponded in essentials to the young Audouinia worms discussed in this paper. In 1887 Cunningham and Ramage gave an account of the spawning of Cirratulus cirratus. They related how the eggs were " enveloped in mucus excreted from the skin " to form little clusters. With the allied Audouinia, in my experience, the discharged eggs are always separate and free. The first figures of larval stages of a Cirratulid were those of Caullery and Mesnil (1898). These larvæ were obtained from their A form of Dodecaceria concharum. The early stages undergo development in the body cavity of the mother, being liberated when about three segments have been marked out between prototroch and telotroch. Apart from the viviparity the development follows fairly closely that of Audouinia, but the larvæ are easily distinguishable by the characteristic shape of the Dodecaceria bristles, the 
succession of which was fully described and figured. In 1911 Sokolow gave a detailed account of the viviparous Ctenodrilus branchiatus Sokolow (=Raphidrilus nemasoma Monticelli). Development continues internally until the young are almost as large as the parent, when they escape by breaking through the body wall. For a time they have branchiæ on most segments but these are subsequently lost. More recently Hofker (1930) has published rough sketches of larvæ from the Zuidersee which he supposes to be those of Streblospio dekhuyzeni Horst. They resemble ordinary Spionid larvæ. Streblospio is regarded by some authorities (e.g. McIntosh) as belonging to the Spionidæ, while others (e.g. Fauvel) class it with the Cirratulidæ.

\section{METHODS.}

After repeated failures to get an artificial fertilisation of Audouinia tentaculata by using eggs and sperm cut from apparently mature adults, it was decided to try to secure naturally spawned eggs. On June 30th, 1928, some worms, newly dug from fairly clean sand on the shore of Drake's Island, were washed in sea water and placed in large glass jars half filled with ordinary aquarium tank water. Two females and one male were put into each jar. The sexes are easily distinguished at maturity by their colour; the middle part of the male's body is bright yellow, that of the female tending to a dark olive. By the next morning (July 1st) one female, but no male, had spawned. The eggs were transferred to finger bowls of sea water that had been brought in from outside the Breakwater, and filtered through a Berkefeld filter, and were fertilised with sperm cut from the body cavity of a male. This gave a successful fertilisation, many larvæ swimming to the surface on July 2nd. Some were transferred to a plunger jar, others to finger bowls. In both kinds of vessel they were reared to early bottom stages. A culture of Nitzschia (kindly supplied by Dr. Allen) was used to feed the young worms after all the yolk had been absorbed.

In the summer of 1933 it was decided to check over the work and several more fertilisations were made in a similar way, only this time a circulation of aquarium water was maintained through the jars in which the adult worms were confined. On most occasions the naturally shed ova were fertilised with sperm freshly cut from the body cavity of a male, but once a male spawned in the same jar and at the same time as a female ; these naturally fertilised eggs gave rise to an exceptionally healthy and vigorous culture. A few experiments were made on eggs cut from the body cavities of apparently mature females, but these eggs never fertilised. Males occasionally shed sperm without stimulating females in the same jar to shed their eggs.

Most of the drawings are from life, made with the aid of a squared net 
micrometer in the eyepiece. They were checked on whole mounts. Figure 11 is from a mounted specimen. Bristles were drawn with a camera lucida. A number of larvæ were sectioned in various planes but owing to the minuteness of the cytological detail little was gained from their study.

\section{The Eggs and Pelagic Stages.}

When the naturally spawned eggs were found it was not known what time had elapsed since shedding, except that it was not likely to have been more than a few hours. By keeping some of the eggs in filtered sea water until they histolysed it was definitely ascertained that they had not been fertilised, with the single exception mentioned above. In the mass they appeared pale green by reflected light; to transmitted light they were almost opaque. The cytoplasm was finely granular and at one place a rather more transparent spot indicated the position of the nucleus. The cytoplasmic mass of the egg (Fig. 1) was shaped slightly like a hen's egg with a long axis of approximately $112 \mu$. It was enclosed in a $5 \mu$ thick egg membrane consisting of at least two layers. For most of the way round the egg this membrane was closely adherent to the cytoplasm, but at the broad end it lifted off the surface to a height of about $9 \mu$ to form a domed cavity about $40 \mu$ in diameter across its floor. The nucleus was situated generally, but not invariably, just below this cavity, the size of which varied considerably; it enlarged slightly in unfertilised eggs on standing. It was not present, nor did it form later, in eggs cut from the body cavity of females, although they were invested in an egg membrane structurally similar. Eggs so obtained directly from the body cavity were irregular in outline and had a conspicuous germinal vesicle of different appearance from the nuclear patch in the naturally shed eggs.

After fertilisation polar bodies are extruded into the domed space and the egg membrane separates from the cytoplasm all round the egg, but the separation is so slight that here and there the two are in contact.

The cilia of the prototroch are first visible when the embryo is about twelve hours old. They are very fine and short and their passage through the thick egg membrane can be seen. At this stage the cells of the embryo are rather large but the egg membrane is not quite completely filled by them. The cilia soon lengthen and begin to beat, moving the embryo slowly over the bottom of the bowl, but they are not sufficiently powerful to raise it from the ground. Eventually they strengthen and their efforts are aided by the telotroch, which becomes visible later than the prototroch. When about twenty-four hours have elapsed the strongly swimming trochosphere (Fig. 2) is fully formed. It is slightly longer than broad and is widest in the region of the prototroch, now a broad band of fine cilia completely encircling the body. The telotroch is also an encircling 
band of fine cilia but it has a short gap in the mid-ventral line. An apical tuft of long and short fine cilia, often twisted together and directed forwards, arises at the anterior end. There are one or two long fine and presumably sensory cilia at the posterior end. The trochosphere is closely enveloped in the thick egg membrane, which from now on forms the cuticle of the larva. The tissues are finely granular and considerably opaque; the central gut region being denser than the rest. The mouth is a very small transverse slit immediately behind the slightly overhanging rim of the prototroch; posterior to it the ventral surface is a little flattened and as yet without the neurotroch. These trochospheres swim at a fast pace, moving in circles or along almost straight courses for relatively long distances, rotating slowly on their longitudinal axes as they go. They do not seem to be in any way phototropic.

Further development consists mainly in the elongation of the trunk, the loss of the long apical cilia and the acquiring of additional cilia on the head and body. A three-day-old larva is shown in dorsal and ventral view in Figures 3 and 4. The trunk is indistinctly segmented, but it is difficult to say of how many segments it is composed, for some of the apparently intersegmental grooves do not completely encircle the body and do not correspond dorsally and ventrally (see lateral view Fig. 7). Septa cannot be seen through the finely granular and moderately opaque body wall. There are no bristles; they do not appear until after metamorphosis. The prototroch is a broad band that narrows slightly in the mid-dorsal

\section{EXPLANATION OF TEXT-FIGURES 1-11.}

Developmental stages of Audouinia tentaculata Montagu. Unless otherwise stated drawn from life; $\times 156$. All measurements given below exclude apical cilia.

FIG. 1.-Recently spawned unfertilized egg (see page 569).

Fig. 2.-Ventral view of trochosphere 24 hours old. Actual length approx. $135 \mu$ (see page 569).

Fig. 3.-Dorsal view of larva three days old. Actual length approx. $245 \mu$ (see page 570).

Fig. 4.-Ventral view of same stage as Fig. 3.

Fig. 5.-Dorsal view of larva seven days old. Actual length approx. $290 \mu$ (see page 572).

Fig. 6.-Ventral view of same stage as Fig. 5.

FIG. 7.-Lateral view of metamorphosing larva ten days old. Actual length approx. $270 \mu$ (see page 573).

Fig. 8.-Dorsal view of young worm fifteen days old. Actual length approx. $335 \mu$ (see page 573).

Fig. 9.-Ventral view of same stage as Fig. 8.

FIG. 10.-Dorsal view of young worm twenty-two days old. Actual length approx. $365 \mu$ (see page 574).

Fig.11.-Lateral view of young worm sixty-three days old. Actual length approx. $800 \mu$. Drawn from a fixed and mounted specimen; $\times 156$.

A. Crotchet of stage of Fig. $10 ; \times 1200$.

B. Simple crotchet of young worm nine months old; $\times 1200$.

C. Toothed crotchet of young worm nine months old ; $\times 1200$. 

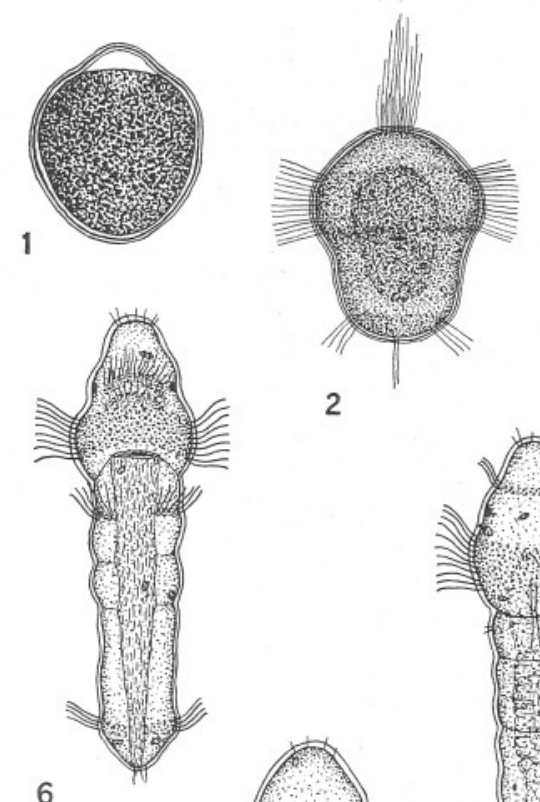

2
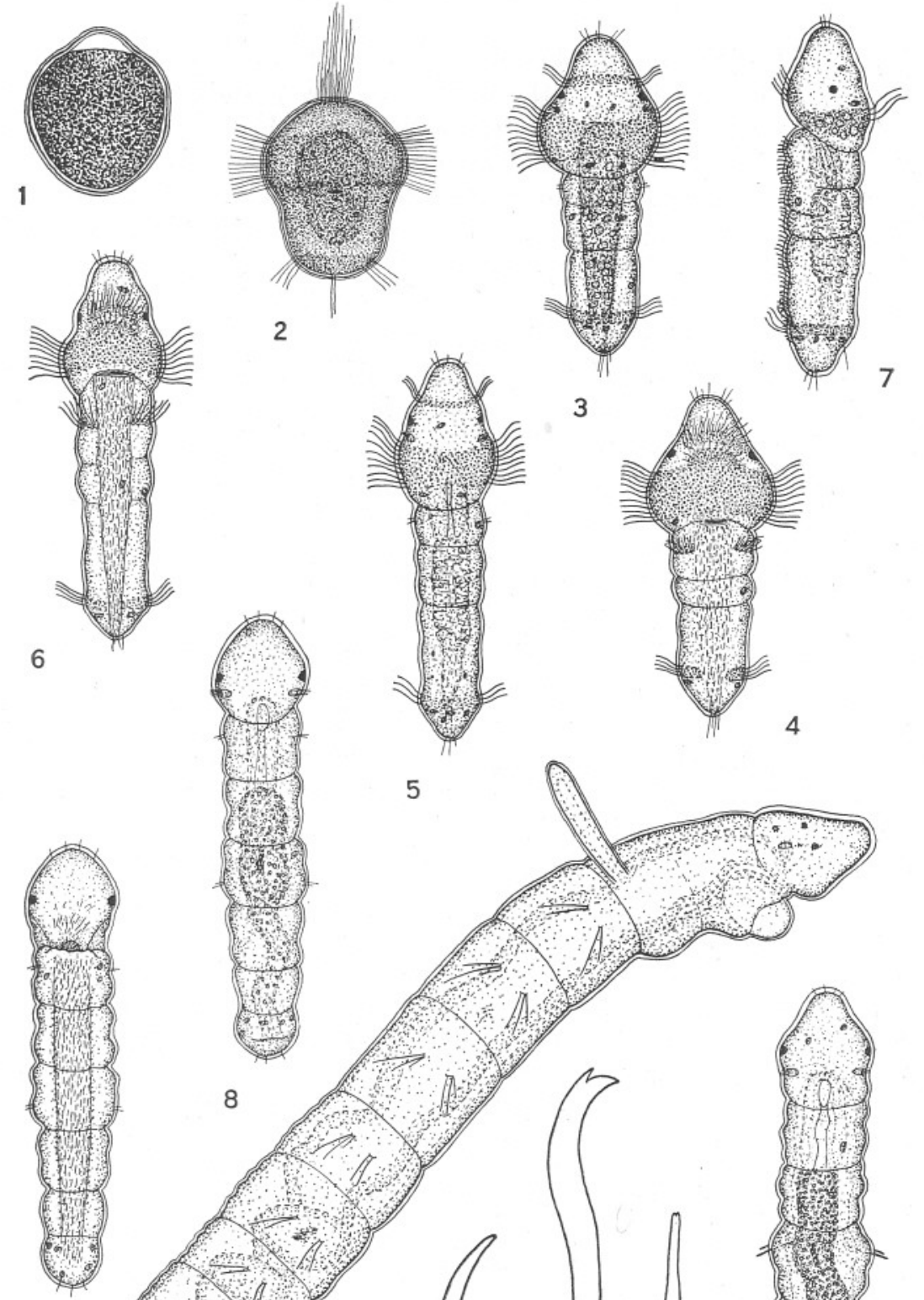

9

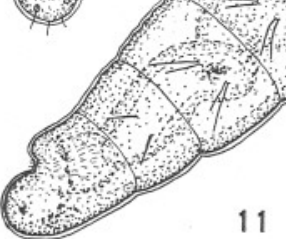

11

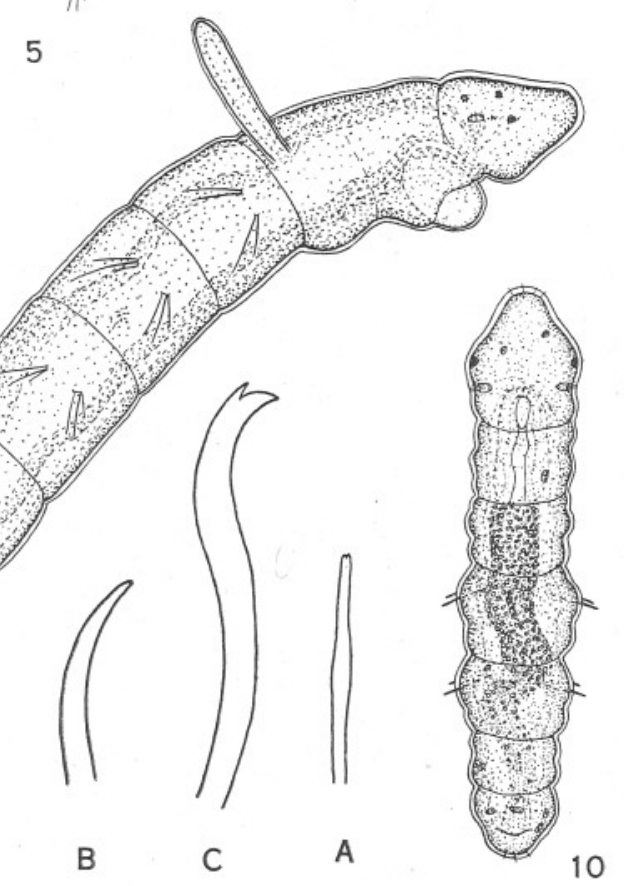

Frgs. 1-11. 
line. The body is of greatest diameter in this region, but as it is actively contractile the relative widths of the various parts are continually changing. Immediately in front of the prototroch there is on either side a minute ciliated pit, the nuchal organ, and in front of this again a cupshaped eye-spot composed of brown oily globules. Across the dorsal surface of the head anterior to the eyes is a band of cilia (the akrotroch) which ends level with the eye on either side. On the ventral surface there are two patches of cilia anterior to the prototroch, one almost semicircular, the other in front of it a curved band. All these head cilia are rather long, fine and actively beating, and in addition there are a few seemingly sensory cilia at the extreme apical end. The mouth opens as a narrow transverse slit ventrally a short distance behind the prototroch ; from it there runs a broad thickly ciliated neurotroch back to the posterior extremity, narrowing a little and passing through the ventral gap in the telotroch. There are a few sensory cilia at the posterior end. On each side of the neurotroch in the anterior part of the trunk there is a short transverse band of fine cilia. These two bands together may be regarded as a gastrotroch with a large mid-ventral gap. One or two short sensory cilia occur on the lateral body walls of this region. The whole larva is enclosed in the two-layered egg membrane (the layers are not indicated in Figs. 3-11), and the cilia can be seen clearly passing through it. The colour of the larva is pale brown by transmitted light and there are a number of brown pigment globules, similar to those composing the eyecups, scattered about the head and body, generally in clusters ; they are specially concentrated behind the telotroch. Little internal structure is visible, except the gut, which now has some large yolk globules in its walls.

The larva slowly elongates and at the same time becomes thinner in a normal state of relaxation-it is very contractile. A seven-day-old larva is shown in Figures 5 and 6 . There has been no great change in structure since the three-day-old larva of the preceding figures. The gut has now three well-marked regions: œsophageal, stomachic and intestinal. The neurotroch has been sunk in a very shallow ventral trough. Very little yolk is left but there is no sign of feeding. The egg membrane forming the cuticle is thinner on the body than on the head. On the former it is $1.5 \mu-2 \mu$ thick, on the latter $2 \cdot 5 \mu-3 \mu$ thick. It is thinner than it was on the egg and earliest stages and appears to have been stretched by growth of the larva inside it. The larva swims relatively fast, mainly in a spiral path. This is the last pelagic stage before metamorphosis. 


\section{Metamorphosis and Early Bottom Stages.}

The individuals in a culture do not metamorphose simultaneously. As is usual with other species, some are more advanced than others. The first larva metamorphosed when about eight days old, the last about five days later.

Metamorphosis consists in loss of most of the cilia. It is interesting in that the cells comprising the prototroch and telotroch are definitely got rid of by internal absorption. In both regions the cilia apparently fall off, not all together but in patches; possibly those belonging to one cell are shed simultaneously. Some little time after the cilia have gone the cell breaks down and its contents round up into large oily looking brown and yellow spheres of varying size and of a type not previously seen and not visible elsewhere in the body. These spheres eventually disappear; there can be little doubt that they are internally absorbed. Figure 7 shows in lateral view a metamorphosing larva. Most of the cilia of the prototroch have fallen off but a small dorsal patch remains. It seems that it is usual for the ventral cilia to go first. Where the cilia have disappeared absorption spheres are seen. The dorsal akrotroch has gone and the ventral anterior crescent of cilia also. The ventral semicircular patch of cilia however remains and it is usual for it to be present for a while after metamorphosis. The gastrotroch has disappeared and in the telotroch only a few of the ventral cilia remain, but the cells that have lost their cilia have not yet broken down into absorption spheres. The neurotroch is scarcely affected by metamorphosis; however, it no longer quite reaches the extremity of the pygidium and in some individuals stops just short of the mouth opening. The buccal organ is fully formed and the creature is beginning to feed. The anus is situated on the dorsal surface of the pygidium.

A specimen a few days after completion of metamorphosis is seen in Figures 8 and 9 . The segmentation is considerably more distinct than formerly and there appear to be five segments between head and pygidium. No chætæ are visible, the short lines that resemble them in the drawings are short, fine, but very stiff cilia, exactly similar to those on the head and pygidium. Sense organs on the head are the eyes and the nuchal organs, both unchanged from the larval stages. Some cilia of the ventral semi-circular patch (there are occasionally signs of the anterior crescentshaped band as well), of the larval head remain, but the patch is now rather irregular and it is in continuity posteriorly with the strongly ciliated dorsal wall of the œsophagus. The buccal organ is large and often protruded; it resembles that of a Terebellid. The lower lip fold is as wide as the body, the mouth itself being very large. The stomach and intestine contain food ; their walls are darkly granular with oily globules, probably 
not yolk globules but absorption products. The gut is longer than the trunk at normal extension, throwing the intestine into folds. Some of the internal septa are now visible. A few brown pigment spots are found here and there on the body wall, especially the pygidium. The cuticle has the usual two-layered appearance and is thickest on the head.

Four or five days later bristles protrude for the first time (Fig. 10). The first pair appears on what is apparently the third segment behind the head; there is one dorsal and one ventral bristle on each side. The next segment also bears bristles and in some specimens at this age the following one also. These bristles are minute crotchets (Fig. A), almost straight with slightly swollen shafts and some, if not all, have a slightly bifurcated tip, this latter feature being very difficult to see. Apart from the bristles the body structure is almost identical with the preceding stage. There is a ciliated proctodæal invagination. The neurotroch extends from just behind the mouth to half way on to the pygidium. The worms crawl actively when stimulated, but normally they glide slowly about the bottom of their bowl, probably on their neurotrochs.

When about five setigers have formed the first branchial filament appears. It arises from the posterior part of the achætous region, immediately in front of the first setiger, and is situated indifferently on either the right or left side. Figure 11 shows a somewhat older worm with a well-grown branchial bud on the right side. There are roughly four eyespots instead of two as formerly but the eye pigment becomes rather irregular from now on. The bristles are more numerous than before. They are mainly crotchets, some plain, others toothed. A few capillary bristles arise dorsally and ventrally in the anterior and middle parapodia.

The worm increases in length and girth by the addition of new segments and by growth of old ones. Additional branchial filaments bud out from the posterior dorsal borders of the achætous region and the first, second, etc., setigers. Their relative lengths are extremely irregular, they are never alike on the two sides and no two individuals ever correspond. Sometimes the branchial filaments of one side are very long, while those of the other side are indicated only by small buds; more often there are long and short on both sides. They often spring so close to the intersegmental grooves that it is difficult to discover to which segment they really belong, but comparison with other individuals shows that these branchial filaments arise from posterior borders of segments with the exception of a pair of buds that sooner or later appears on the anterior part of the second setiger. A small bud of this type is seen in Figure 12 on the right side just behind the intersegmental groove between setigers one and two-the left bud has not yet developed. These buds arise a little nearer to the mid-dorsal line than do those of the branchial filaments 
and sometimes are inserted in the intersegmental groove, when it becomes difficult to ascertain whether they belong to the first or the second setiger. There are indications that they sometimes belong to the first. They

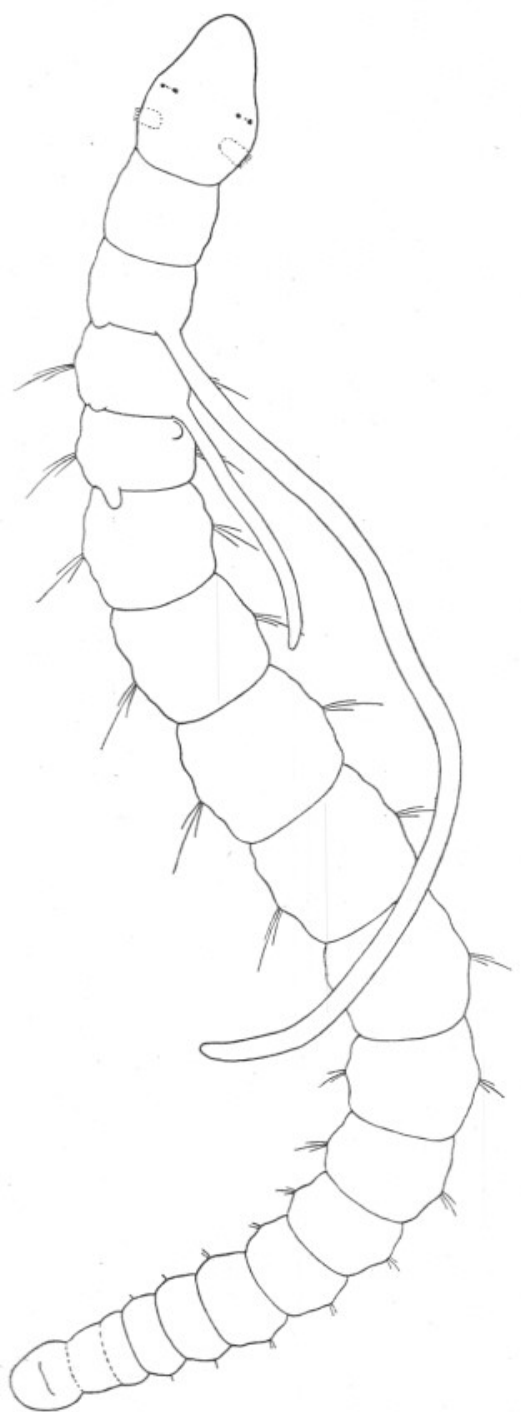

FIG. 12.-Dorsai view of young Audouinia tentaculata Montagu three months old. Drawn from life; $\times 120$. Actual length approx. $2 \mathrm{~mm}$.

grow out into rather thicker filaments than the ordinary branchial filaments and are probably homologous with the tentacular filaments of the adult and other Cirratulids. These latter are usually distinguished 
from the branchial filaments by the possession of only one blood vessel instead of two; unfortunately I have not been able to satisfy myself that these minute filaments in the young worm possess only one vessel, so that this distinction cannot here be used.

Figure 12 shows a typical specimen selected from a number of worms three months old that since metamorphosis had been kept in a flatbottomed glass dish containing fine sandy gravel, which had originally been washed clean and boiled to ensure that any life it might have contained was killed. The branchial details of this specimen have been discussed in the preceding paragraph but a few other points are worthy of mention. The fourteen setigers all bear dorsal and ventral bristle bundles. Anteriorly long capillary bristles predominate; these become scarcer and shorter posteriorly and the last few segments bear only crotchets. The crotchets are either simple or carry a secondary tooth above the first. They are most numerous in the middle region of the body. The minute crotchets that first appeared (Fig. A) have either grown larger and been transformed by wear or have fallen out. The neurotroch runs from the mouth to the intersegmental groove between the second and third setigers, where it ceases ; it is thus relatively shorter than it was during early post-metamorphosis stages and is confined to those segments that were formed during larval life. It persists thus to the latest stage to which I have reared the worms. The anus is dorsal. The tissues of this very contractile worm are transparent and the whole animal is enclosed in a cuticle which in its two-layered appearance is identical with that of the larva.

The most advanced specimen I have reared and actually fixed and mounted is nine months old and has over forty setigers. In its preserved state it is five to six millimetres long and about half a millimetre maximum diameter of body. The anterior parapodia each carry a few long capillary bristles and crotchets. As before the posterior bristles are mainly crotchets. The crotchets are of two kinds, plain (Fig. B) or with a secondary tooth (Fig. C). The first pair of long branchiæ springs from the posterior border of the achætigerous region. The first setiger bears branchial buds only. The second setiger bears a long branchia on either side from just above and close behind the parapodia, while nearer the mid-dorsal line a pair of thicker "tentacular processes " arise, the righthand one being much longer than the left. Their positions of attachment are so close to the intersegmental junction between the second and third setigers as to make it a little doubtful whether they should not really be ascribed to the third setiger. The third setiger bears two long branchiæ inserted as usual dorsal and posterior to the parapodia. The fourth and fifth setigers each carry a long branchia on the right but have buds only on the left. This arrangement is reversed on the sixth setiger. The seventh 
carries a very small bud on either side and there is one tiny bud on the left side of the eighth. The ninth has a fairly large branchial bud on the left side. Eye-like pigment spots are still present in this specimen.

Two other worms, the same age as the preceding but possessing only 25 and 30 setigers respectively, correspond in most details excepting that they have fewer branchiæ and that the thicker "tentacular filaments," of which each has a pair, spring from the anterior part of the second setiger.

\section{Discussion.}

While the actual pelagic stages of this worm are of little interest, apart from the unusual feature for a Polychæte larva of the absence of bristles, the appearance of which is delayed until after metamorphosis, the early bottom stages raise several points requiring attention. The most puzzling feature is the position of those filaments I have ventured to homologize with the tentacular filaments of the adult. In these young worms they arise on segments well anterior to those which normally carry them in the adult (setigers 6-7). Perhaps it may be assumed that with growth these tentacular filaments in the region of the intersegmental groove between first and second setigers are lost and replaced by others further back. The condition of the most advanced specimen described above, in which these filaments arise from the intersegmental region between the second and third setigers, may be a hint of this, but otherwise the worms have not survived long enough for this process to be observed.

The young worms also differ from the adults in that the first pair of branchial filaments springs from the achætigerous region. In all the adults $I$ have examined they have never been inserted further forward than the posterior border of the first setiger; this is in accordance with general descriptions of this worm. In Cirratulus norvegicus Southern (1914), which Fauvel (1927) regards as a variety of Audouinia tentaculata Montagu, a pair of branchiæ does arise, however, from the posterior border of the achætigerous region. This condition in any case is probably more primitive than that of the adult $A$. tentaculata. Southern's $C$. norvegicus also approaches my young $A$. tentaculata in that the tentacular filaments spring from a more anterior setiger (the fourth) than in the adult of the latter species. In passing one may remark that the characters, including size and number of segments, by which Southern (p. 109) distinguishes $C$. norvegicus from $A$. tentaculata are in general those that may occur in young of the latter species. Southern however records (p. 108) that he obtained one mature female of $C$. norvegicus, which after all may quite well be a good species.

In connection with the branchiæ it may be noted that McIntosh (1915, p. 246) records two specimens of Cirratulus (Audouinia) filigerus from 
Naples in which " a branchia springs in front of the dorsal of the first series of bristles." In Fauvel's later description of Audouinia filigera (1927, p. 93) the first pair of branchiæ arises from the first setiger.

The anterior achætigerous region of the adult is usually regarded as being composed of three segments, in addition to the prostomium, but there does not seem to be any real evidence in support of this view. It is true that the region is roughly equivalent in length to three of the immediately succeeding setigers, but this is not necessarily a safe criterion to adopt. The external annulations are numerous and rather irregular, so that it is not possible with certainty to pick out intersegmental grooves. This remark applies also to the larvæ and young worms, though in the latter the intersegmental annulations do appear for a time to be rather more definite than in the adult and they mark out two achætigerous segments rather than three. Thus in my drawings I have indicated this region as composed of two segments only but it must be remembered that in the living worms, especially stages as late as Figure 12, the segmentation was by no means as definite as the figures would lead one to suppose. Sections of larvæ and young worms do not help in deciding the matter. Cunningham and Ramage long ago pointed out that the achætigerous region is devoid of septa and that the ventral nerve cord does not extend further forward than the first setiger. In very young larvæ the tissues are too minute, compact and yolky to permit of the point being settled by examination of the condition of the early mesoderm.

In the young Audouinia many of the crotchets bear a secondary tooth above the main one (Fig. C), whereas in the adult all the crotchets are plain and resemble the simple ones of the young worms (Fig. B). Bidentate crotchets are found in the adults of the allied genus Heterocirrus Grube and they are closely similar in shape to those of the young Audouinia.

In conclusion it seems important to emphasize that young Audouinia tentaculata worms nine months old and with over forty segments differ so much in appearance from the adult that had they been collected directly from the sea it would have been extremely difficult, if not impossible, to have identified them. Indeed they might very easily have been regarded as a new species. The same may be said of a number of other Polychætes which have been reared from the egg; the young worms only very slowly acquire those characters by which the genus and species are recognized. This is, of course, in accordance with general evolutionary theory, but is none the less disconcerting to the worker attempting to identify pelagic Polychæte larvæ by keeping the young worms after metamorphosis until they have grown up to be recognizable. 


\section{SUMMARY.}

(1) Adults of Audouinia tentaculata Montagu were induced to spawn in the laboratory; the eggs were fertilized and the larvæ reared to metamorphosis and early bottom stages for the first time.

(2) The larvæ are yolky and do not feed. They have a broad prototroch and telotroch and a broad neurotroch. The ciliation of the head is rather complex. There are no bristles. When about ten days old they metamorphose.

(3) During metamorphosis most of the cilia, except those of the neurotroch, disappear and their cells are absorbed internally.

(4) Bristles appear for the first time a few days after metamorphosis. After a while branchiæ appear, followed by what are apparently tentacular filaments situated on segments anterior to those on which they occur in the adult.

(5) Discussion centres on the position of the tentacular filaments and the first pair of branchiel filaments in the young worm as compared with the adult. The segmentation of the anterior achætigerous region also receives attention.

\section{REFERENCES.}

Caullery, M. et Mesnil, F. 1898. “ "Les formes épitoques et l'évolution des Cirratuliens.” Ann. Univ. de Lyon, Fasc. XXXIX.

Claparède, E. u. Mecznikow, E. 1868. "Beiträge zur Kenntniss der Entwicklungsgeschichte der Chætopoden." Zeit. wiss. Zool., Bd. XIX.

Cunningham, J. T., and Ramage, G. A. 1888. "The Polychæta Sedentaria of the Firth of Forth." Trans. Roy. Soc. Edin., Vol. XXXIII, p. 635.

Fauvel, P. 1927. Polychètes Sédentaires. Faune de France. 16.

Hofker, J. 1930. "Faunistische Beobachtungen in der Zuidersee während der Trockenlegung." Meded. Zuiderzee-Com. Afl. 2.

McIntosh, W. C. 1915. A Monograph of the British Marine Annelids. Vol. III. Ray Society.

Sokolow, I. 1911. "Über eine neue Ctenodrilusart und ihr Vermehrung.” Zeit. wiss. Zool., Bd. XCVII, p. 546.

Southern, R. 1914. "Archiannelida and Polychæta." Clare Island Survey. Proc. Roy. Irish Acad., Vol. XXXI, Section 2, Part 47. 